\title{
STRATEGI PENGARUH GAYA KEPEMIMPINAN TERHADAP KINERJA KARYAWAN PADA PT.PLN (Persero) AREA SITUBONDO
}

\author{
Ayu Putri Agustin ${ }^{1}$, Pudjo Suharso ${ }^{1}$, Sukidin ${ }^{1}$ \\ ${ }^{1}$ Program Studi Pendidikan Ekonomi, Fakultas Keguruan dan Ilmu Pendidikan Universitas Jember \\ E-mail : ayuputriagustin4@gmail.com
}

\begin{abstract}
Abstrak
Penelitian ini dilakukan untuk mengetahui pengaruh yang signifikan antara gaya kepemimpinan terhadap kinerja karyawan pada PT. PLN (Persero) Area Situbondo. Metode penentuan lokasi penelitian menggunakan metode purposive area yaitu di PT. PLN (persero) Area Situbondo. Penentuan jumlah responden dalam penelitian ini menggunakan metode Total Sampling yaitu sebanyak 40 responden. Metode pengumpulan data yang digunakan terdiri dari metode: angket, observasi, wawancara, dan dokumen. Uji instrumen data dalam penelitian ini menggunakan uji validitas dan uji reliabilitas. Teknik pengolahan data dalam penelitian ini menggunakan editing, skoring, dan tabulasi. Analisis data yang digunakan adalah analisis inferensial/statistik yaitu dengan menggunakan analisis garis regresi sederhana, analisis varian garis regresi, uji F, dan koefisien determinasi. Hasil penelitian menunjukkan bahwa ada pengaruh yang signifikan variabel gaya kepemimpinan terhadap kinerja karyawan pada PT. PLN (Persero) Area Situbondo yang dapat dilihat dari besarnya $F_{\text {hitung }}=157,380>F_{\text {tabel }}=4,10$ dengan tingkat signifikansi $\mathrm{F}=0,000<a=0,05$. Besarnya besarnya persentase gaya kepemimpinan terhadap kinerja karyawan pada PT. PLN (Persero) Area Situbondo sebesar 80,6\%. sedangkan sisanya yaitu 19,4\% dipengaruhi variabel bebas lainnya yang tidak diteliti dalam penelitian ini seperti masa kerja, beban kerja, pelatihan karyawan, gaji, dan lain-lain.
\end{abstract}

Kata Kunci: Gaya Kepemimpinan dan Kinerja Karywan

\section{PENDAHULUAN}

Sumber daya manusia merupakan, suatu aspek yang penting untuk mencapai tujuan dalam sebuah organisasi atau perusahaan. Setiap perusahaan membutuhkan sumber daya manusia yang berkualitas baik sebagai pemimpin maupun karyawan, karena sumber daya manusialah yang membuat rencana - rencana kerja serta pengawasan untuk mencapai tujuan perusahaan.

PT. PLN (Persero) adalah sebuah BUMN yang mengurusi semua aspek kelistrikan yang ada di Indonesia. Ketenagaan listrik di Indonesia dimulai pada akhir abad ke-19, ketika beberapa perusahaan Belanda mendirikan pembangkit tenaga listrik untuk keperluan sendiri. Pada era modern ini PLN berperan penting bagi kehidupan keseharian masyarakat Indonesia terutama masyarakat Situbondo, dimana saat ini listrik menjadi salah satu kebutuhan utama masyarakat terutama perusahaan-perusahaan atau industri-industri yang berada di kabupaten Situbondo.

Menurut informasi dari karyawan yang dilakukan oleh peneliti kepemimpin di PT. PLN (Persero) Area Situbondo senantiasa melibatkan berbagai hal, pemimpin senantiasa memberikan wewenang, tanggung jawab kepada karyawan untuk melakukan pekerjaan dan senantiasa selalu mengikut sertakan karyawannya dalam mengambil keputusan. Pemimpin yang efektif harus mampu menganalisis kekuatan dan kelemahan sumberdaya manusiannya sehingga mampu memaksimalkan kinerja organisasi atau perusahaan dan memecahkan masalah dengan tepat.

Gaya kepemimpinan merupakan norma perilaku yang digunakan oleh seseorang pada saat orang tersebut mencoba mempengaruhi perilaku orang lain atau bawahan (Thoha, 2013:49). Menurut Tjiptono (2006:161) gaya kepemimpinan adalah suatu cara yang digunakan pemimpin dalam berinteraksi dengan bawahannya. Sedangakan menurut Thoha (2010:49) menyebutkan bahwa gaya kepemimpinan adalah norma perilaku yang digunakan oleh seseorang pada saat orang tersebut mencoba mempengaruhi prilaku orang lain atau bawahan. Selain itu menurut Robbins (2005:80) gaya kepemimpinan merupakan cara yang digunakan seseorang untuk mempengaruhi kelompok menuju tercapainya sasaran.

Berdasarkan pengertian-pengertian gaya kepemimpinan diatas dapat disimpulkan bahwa gaya kepemimpinan adalah kemampuan seseorang pemimpin dalam mengarahkan, mempengaruhi, mendorong dan mengendalikan orang bawahan untuk bisa melakukan sesuatu pekerjaan atas kesadarannya dan sukarela dalam mencapai suatu tujuan tertentu. Berbicara mengenai gaya kepemimpinan tentu tak terlepas dari hasil yang dicapai 
atau kinerja, baik itu kinerja dari pemimpin maupun kinerja karyawannya. Gaya kepemimpinan yang diterapkan oleh seorang pemimpin di dalam suatu perusahaan memegang kunci utama dalam tercapainya lingkungan kerja yang baik. Dalam rangka meningkatkan motivasi karyawan yang dilakukan oleh pemimpin berdampak pada peningkatan produktivitas dan kinerja karyawan, sehingga tujuan utama yang di inginkan dicapai oleh perusahaan dapat terwujud. Menurut Salusu (2006:204-205) Indikator Gaya Kepemimpinan adalah Inisiatif, Inquiry (Menyelidiki), Advocacy (Dukungan atau Dorongan), Conflict Solving (Memecahkan Masalah), Decision Making (Pengambilan Keputusan), dan Critique (Kritik).

Kinerja merupakan suatu hasil secara kualitas maupun kuantitas yang telah dicapai seseorang karyawan dalam melaksanakan tugas dan tanggung jawab yang telah diberikan kepadanya (Mangkunegara,2006:67). Karena pada hakikatnya setiap perusahaan tentunya menginginkan kinerja yang bagus dan bermutu tinggi. Untuk meningkatkan kinerja seseorang dalam perusahaan tidaklah mudah, karena kinerja yang baik secara langsung akan mempengaruhi kinerja perusahaan dan untuk memperbaiki kinerja karyawan tentu merupakan suatu pekerjaan yang memakan waktu dan proses yang cukup lama. Dimana kinerja itu sendiri merupakan kombinasi dari usaha, kemampuan dan kesempatan yang dapat dinilai dari hasil kerjannya. Karena keberhasilan kinerja dapat diukur melalui kepuasan konsumen, berkurangnnya keluhan dan tercapainnya target yang optimal. Kinerja di PT. PLN (Persero) Area Situbondo juga dapat diukur melalui penyelesaian tugasnya secara efektif dan efisien serta melakukan peran dan fungsinya, itu semua berhubungan linier dan berhubungan positif bagi keberhasilan suatu perusahaan.

Jadi, kinerja merupakan suatu gambaran mengenai tingkat pencapaian pelaksanaan suatu kegiatan atau program perusahaan dalam mewujudkan sasaran, tujuan,misi,visi serta organisasi. Pada dasarnya pengertian kinerja berkaitan dengan tanggung jawab individu atau organisasi dalam menjalankan apa yang menjadi wewenang dan tanggung jawab yang diberikan kepadanya. Dari berbagai definisi kinerja di atas, dapat disimpulkan bahwa kinerja adalah suatu hasil kerja yang dapat dicapai seseorang atau sekelompok orang dalam suatu perusahaan sesuai wewenang dan tanggung jawabnya untuk mencapai tujuan perusahaan. Menurut Robbins (2006:260) Indikator untuk mengukur kinerja karyawan ada lima indikator, yaitu; kualitas, kuantitas, ketepatan waktu, dan efektivitas, kemandirian.

Gaya kepemimpinan seorang pemimpin pada dasarnya dapat mempengaruhi perilaku bawahan agar mampu melaksanakan tugas atau kegiatan dengan sebaik-baiknya. Karyawan atau bawahan akan mampu mencapai produktivitas kerja secara maksimal jika memiliki motivasi yang berasal dari dirinya sendiri maupun yang berasal dari lingkungan kerja. Dalam kaitannya dengan hal tersebut, maka seorang pemimpin dituntun memiliki kemampuan mempengaruhi dan memberikan motivasi kepada karyawannya agar bisa bekerja secara maksimal.

Thoha (2010:42), mengungkapkan bahwa dengan mempergunakan kepemimpinan maka pemimpin akan mempengaruhi persepsi bawahan dan memotivasinya, dengan cara mengarahkan karyawan pada kejelasan tugas, pencapaian tujuan, kepuasan kerja, dan pelaksanaan kerja yang efektif. Hal ini dipertegas oleh Robbins (2007:432), yang mengungkapkan bahwa kepemimpinan sebagai kemampuan untuk mempengaruhi suatu kelompok menuju pencapaian sasaran. Kemampuan karyawan untuk mencapai sasaran dan tujuan organisasitersebut merupakan pencerminan dari kinerja karyawan. Sehingga dapat disimpulkan jika gaya kepemimpinan memiliki peran yang besar dalam meingkatkan kinerja karyawan

Keberhasilan perusahaan pada dasarnya ditopang oleh kepemimpinan yang efektif. Menurut Siagian (2001:145) mengungkapkan bahwa pemimpin yang efektif adalah pimpinan yang mampu menunjukkan jalan yang dapat ditempuh oleh bawahan sehingga gerak dari posisi sekarang ke posisi yang diinginkan di masa yang akan datang dapat berlangsung lancar sehingga produktivitas dapat tercapai. Seorang pemimpin dalam organisasi menjadi tonggak keberhasilan dalam pencapaian tujuan organisasi.Kepemimpinan yang dijalankan ini sedikit banyak juga berpengaruh terhadap kinerja pegawai organisasi yang bersangkutan. Artinya kepemimpinan ini merupakan faktor dalam mempengaruhi penampilan dan aktivitas bawahan dalam pencapaian tujuan.

Mengacu penjelasan di atas, maka dapat diambil suatu hipotesis penelitian yang dapat digunakan sebagai dasar dilakukannya penelitian ini yaitu: "Diduga ada pengaruh yang signifikan antara gaya kepemimpinan terhadap kinerja karyawan pada PT. PLN (Persero) Area Situbondo".

\section{METODE}

Penelitian ini merupakan penelitian kuantitatif, yaitu untuk mengetahui pengaruh gaya kepemimpinan terhadap kinerja karyawan PT. PLN (Persero) Area Situbondo. Metode penentuan lokasi penelitian menggunakan metode purposive area yaitu di PT. PLN (persero) Area Situbondo yang beralamat di Sumber Kolak, Panarukan, Kabupaten Situbondo, Jawa Timur 68312. Penentuan jumlah responden dalam penelitian ini menggunakan metode Total Sampling yaitu sebanyak 40 responden. Metode pengumpulan data yang digunakan terdiri dari metode: angket, observasi, wawancara, dan dokumen. Uji instrumen data dalam penelitian ini menggunakan uji 
validitas dan uji reliabilitas. Teknik pengolahan data dalam penelitian ini menggunakan editing, skoring, dan tabulasi. Analisis data yang digunakan adalah analisis inferensial/statistik yaitu dengan menggunakan analisis garis regresi sederhana dengan rumus sebagai berikut:

$$
\hat{\mathrm{Y}}=\mathrm{a}+\mathrm{bX}+e i
$$

Untuk analisis varian garis regresi yaitu untuk mengetahui kuat tidaknya atau tingkat keeratan variabel gaya kepemimpinan terhadap kinerja karyawan PT. PLN (Persero) Area Situbondo yaitu dengan rumus sebagai berikut:

$$
\mathrm{Ry}=\sqrt{\frac{a \sum X Y}{\sum Y^{2}}}
$$

Sedangkan uji F yaitu untuk mengetahui pengaruh yang signifikan variabel gaya kepemimpinan terhadap kinerja karyawan PT. PLN (Persero) Area Situbondo dengan rumus sebagai berikut:

$$
F_{\text {reg }=} \frac{\mathrm{R}^{2} / \mathrm{K}}{\left(1-\mathrm{R}^{2}\right) /(\mathrm{n}-\mathrm{k}-1)}
$$

Selanjutnya, untuk uji koefisien determinasi yaitu untuk mengetahui berapa besar (\%) pengaruh variabel gaya kepemimpinan terhadap kinerja karyawan PT. PLN (Persero) Area Situbondo.

\section{HASIL PENELITIAN}

Berdasarkan hasil analisis garis regresi sederhana diperoleh $\mathbf{R}_{\text {square }}$ sebesar 0,806 . Koefisien determinasi $\mathrm{R}_{\text {square }}$ dalam penelitian ini digunakan untuk mengukur besarnya pengaruh variabel bebas $(\mathrm{X})$ dan variabel terikat (Y). Jenis analisis ini digunakan untuk mengetahui pengaruh yang signifikan dari variabel bebas yaitu variabel gaya kepemimpinan terhadap kinerja karyawan pada PT. PLN (Persero) Area Situbondo. Berdasarkan analisis data yang dilakukan diperoleh hasil dalam tabel berikut ini:

Tabel Ringkasan Uji F, Multiple R, dan R Square

\begin{tabular}{lcccccc}
\hline Variabel & $\mathrm{F}_{\text {Hitung }}$ & $\mathrm{F}_{\text {Tabel }}$ & Sig. F & $a$ & $\mathrm{R}$ & $\mathrm{R}_{\text {Square }}$ \\
\hline X terhadap Y & 157,380 & 4,10 & 0,000 & 0,05 & $0,898^{\mathrm{a}}$ & 0,806 \\
\hline
\end{tabular}

Sumber : Data diolah 2018

Tabel di atas menunjukkan bahwa $\mathrm{F}_{\text {hitung }}=157,380>\mathrm{F}_{\text {tabel }}=4,10$ dengan tingkat signifikansi $\mathrm{F}=0,000$ $<a=0,05$. Hal ini menunjukkan bahwa variabel gaya kepemimpinan memiliki pengaruh yang signifikan terhadap kinerja karyawan pada PT. PLN (Persero) Area Situbondo. Untuk koefisien determinasi R Rquare sebesar 0,806, yang dengan proporsi sumbangan variabel $\mathrm{X}$ terhadap $\mathrm{Y}$ sebesar $80,6 \%$. sedangkan sisanya yaitu 19,4\% dipengaruhi variabel bebas lainnya yang tidak diteliti dalam penelitian ini seperti masa kerja, beban kerja, pelatihan karyawan, gaji, dan lain-lain.

\section{PEMBAHASAN}

Peran seorang pemimpin dalam mempengaruhi bawahannya sangatlah penting bagi kemajuan organisasi tersebut. Koesmono (2007:30) mengungkapkan bahwa keberadaan seorang pemimpin dalam organisasi dibutuhkan untuk membawa organisasi kepada tujuan yang telah ditetapkan. Pemimpin biasanya menerapkan gayakepemimpinan tertentu untuk mempengaruhi kinerja bawahannya, sehingga tujuan utama yang ingin dicapai oleh perusahaan dapat terwujud. Kepemimpinan yang efektif adalah pemimpin yang dapat menyesuaikan gaya kepemimpinannya sesuai dengan tingkat kematangan karyawan.

Penelitian ini dilakukan untuk mengetahui pengaruh yang signifikan antara gaya kepemimpinan terhadap kinerja karyawan pada PT. PLN (Persero) Area Situbondo. Hipotesis yang menyatakan bahwa diduga ada pengaruh yang signifikan antara gaya kepemimpinan terhadap kinerja karyawan pada PT. PLN (Persero) Area Situbondo diterima atau mempunyai pengaruh positif yang signifikan terhadap kinerja karyawan. Hal ini artinya hipotesis tersebut terjawab secara simultan gaya kepemimpinan berpengaruh terhadap kinerja karyawan sebesar $80,6 \%$.

Pada suatu perusahaan seperti halnya pada PT. PLN (Persero) Area Situbondo, kesuksesan atau 
kegagalan dalam pelaksanaan tugas dan penyelenggaraan, dipengaruhi kepemimpinan dan didukung oleh kapasitas organisasi yang memadai. Kepemimpinan dapat dikatakatakan sebagai cara dari seorang pemimpin dalam mengarahkan, mendorong dan mengatur seluruh unsur-unsur didalam kelompok atau organisasi untuk mencapai suatu tujuan organisasi yang diinginkan sehingga menghasilkan kinerja karyawan berarti tercapainya hasil kerja karyawan dalam mewujudkan tujuan pada PT. PLN (Persero) Area Situbondo tersebut. Selain kepemimpinan, didalam sebuah perusahaan seperti pada PT. PLN (Persero) Area Situbondo juga didukung oleh para karyawan yang mempunyai kinerja yang bagus sehingga tujuan perusahaan dapat terlaksana. Karyawan dan pemimpin mempunyai kontribusi yang sangat besar terhadap perusahaan, karena tanpa keduanya perusahaan tidak akan berjalan. Oleh karena pemimpin harus bisa menempatkan perannya sebagai kepala semua bidang diperusahaan sehingga dapat mengatur para karyawan agar bekerja dengan baik dan juga bisa memotivasi karyawan.

Setiap pemimpin pada dasarnya memiliki perilaku yang berbeda-beda dalam memimpin karyawannya, dan pelaku pemimpin tersebut disebut dengan gaya kepemimpinan, dimana gaya kepemimpinan tersebut banyak mempengaruhi keberhasilan seorang pemimpin dalam mempengaruhi karyawannya. Menurut Tjiptono (2006:161) gaya kepemimpinan adalah suatu cara yang digunakan pemimpin dalam berinteraksi dengan bawahannya. Sedangkan menurut Miftah Thoha (2010:49) menyebutkan bahwa gaya kepemimpinan adalah norma perilaku yang digunakan oleh seseorang pada saat orang tersebut mencoba mempengaruhi prilaku orang lain atau bawahan. Jadi, gaya kepemimpinan merupakan kemampuan seseorang pemimpin dalam mengarahkan, mempengaruhi, mendorong dan mengendalikan orang bawahan untuk bisa melakukan sesuatu pekerjaan atas kesadarannya dan sukarela dalam mencapai suatu tujuan tertentu.

Selain itu, gaya kepemimpinan yang dimaksud dalam penelitian ini adalahkecenderungan seseorang pemimpin dalam interaksinya dengan bawahan, yang agak khas dan konsisten sifatnya.Sikap tersebut adalah sebuah ketrampilan yang perlu dilakukan oleh pimpinan baik muncul dalam diri sendiri maupun karena melihat metode pemimpin pada lembaga-lembaga lain dalam rangka untuk melaksanakan tugasdalam pencapaian tujuan.

Gaya kepemimpinan tersebut merupakan bentuk tingkat ketrampilan bagi setiap pemimpin dalam menjalankan roda organisasi dengan harapan untuk mencapai tujuan yang ingin dicapai dalam sebuah lembaga atau instansi tersebut. Namun pada dasarnya, untuk lebih kompletnya dan bisa terterima oleh bawahan, seorang pemimpin harus mampu mengkolaborasikan gaya tersebut untuk diterapkan dalam organisasi yang dipimpinnya. Indikator gaya kepemimpinan yang digunakan dalam penelitian ini meliputi: Inisiatif, Advocacy (Dukungan atau Dorongan), Conflict Solving (Memecahkan Masalah), Decision Making (Pengambilan Keputusan) dan Critique (Kritik). Berikut merupakan hasil wawancara yang dilakukan oleh peneliti dengan salah satu informan dalam penelitian ini.

“............................ untuk mengambil suatu keputusan jika itu perlu dirundingkan dengan bawahan saya, pasti saya ajak mereka diskusi dan mencari solusinya. Jika sudah benar-benar fix dan semuanya setuju, baru keputusan tersebut diambil" (NP, $\left.48^{\mathrm{Th}}\right)$.

Berdasarkan hasil wawancara yang dilakukan peneliti tersebut dapat diketahui bahwa gaya kepemimpinan yang diterapkan oleh pihak PT. PLN (Persero) Area Situbondo pemimpin yang cenderung melibatkan karyawan dalam mengambil keputusan, mendelegasikan wewenang, mendorong partisipasi dalam memutuskan metode dan sasaran kerja, dan menggunakan umpan balik sebagai peluang untuk melatih karyawan. Hal ini menunjukkan bahwa gaya kepemimpinan yang diterapkan melihat kondisi karyawan serta menyesuaikan dengan beban kerja para karyawan tersebut.

Adanya gaya kepemimpinan yang diterapkan pada PT. PLN (Persero) Area Situbondo diharapkan dapat meningkatkan kinerja karyawan. Gaya kepemimpinan seorang pemimpin pada dasarnya dapat mempengaruhi perilaku bawahan agar mampu melaksanakan tugas atau kegiatan dengan sebaik-baiknya. Karyawan atau bawahan akan mampu mencapai produktivitas kerja secara maksimal jika memiliki motivasi yang berasal dari dirinya sendiri maupun yang berasal dari lingkungan kerja. Dalam kaitannya dengan hal tersebut, maka seorang pemimpin dituntun memiliki kemampuan mempengaruhi dan memberikan motivasi kepada karyawannya agar bisa bekerja secara maksimal. Berikut merupakan hasil wawancara yang dilakukan oleh peneliti dengan salah satu informan dalam penelitian ini.

“...........................tata cara dalam memimpin pada PLN ini sangat mempengaruhi kinerja karyawan dek. Hal ini dikarenakan dengan tata cara kepemimpinan yang sesuai dengan kondisi dan keinginan karyawan, maka akan membuat karyawan betah sehingga kinerja karyawan akan tinggi. Akan tetapi jika tata cara dalam memimpin tidak sesuai dengan kondisi dan keinginan karyawan, maka banyak dari karyawan yang tidak betah, dan tentu saja hal tersebut membuat kinerja karyawan akan menurun" (NP, $\left.48^{\mathrm{Th}}\right)$.

Berdasarkan hasil wawancara tersebut dapat diketahui bahwa gaya kepemimpinan yang diterapkan pada 
PT. PLN (Persero) Area Situbondo dapat mempengaruhi kinerja karyawan. Hal ini dikarenakan dengan dengan tata cara kepemimpinan yang sesuai dengan kondisi dan keinginan karyawan, maka akan membuat karyawan betah sehingga kinerja karyawan akan tinggi. Akan tetapi jika tata cara dalam memimpin tidak sesuai dengan kondisi dan keinginan karyawan, maka banyak dari karyawan yang tidak betah sehingga kinerja karyawan akan menurun.

Hal tersebut sesuai dengan pendapat Thoha (2010:42), mengungkapkan bahwa dengan mempergunakan kepemimpinan maka pemimpin akan mempengaruhi persepsi bawahan dan memotivasinya, dengan cara mengarahkan karyawan pada kejelasan tugas, pencapaian tujuan, kepuasan kerja, dan pelaksanaan kerja yang efektif. Hal ini dipertegas oleh Robbins (2007:432), yang mengungkapkan bahwa kepemimpinan sebagai kemampuan untuk mempengaruhi suatu kelompok menuju pencapaian sasaran. Kemampuan karyawan untuk mencapai sasaran dan tujuan organisasitersebut merupakan pencerminan dari kinerja karyawan. Sehingga dapat disimpulkan jika gaya kepemimpinan memiliki peran yang besar dalam meningkatkan kinerja karyawan.

Kinerja karyawan adalah suatu hasil kerja yang dapat dicapai seseorang atau sekelompok orang dalam suatu perusahaan sesuai wewenang dan tanggung jawabnya untuk mencapai tujuan perusahaan seperti padaPT. PLN (Persero) Area Situbondo. Pada dasarnya kinerja berkaitan dengan tanggung jawab karyawan dalam menjalankan apa yang menjadi wewenang dan tanggung jawab yang diberikan kepadanya. Adapun indikatorindikator kinerja karyawan dalam penelitian ini yaitu kualitas, kuantitas, ketepatan waktu, efektivitas dan kemandirian.

Keberhasilan perusahaan pada dasarnya ditopang oleh kepemimpinan yang efektif. Menurut Siagian (2001:145) mengungkapkan bahwa pemimpin yang efektif adalah pimpinan yang mampu menunjukkan jalan yang dapat ditempuh oleh bawahan sehingga gerak dari posisi sekarang ke posisi yang diinginkan di masa yang akan datang dapat berlangsung lancar sehingga produktivitas dapat tercapai.

“.................,pimpinan kami juga memperhatikan kemampuan karyawannya, contohnya dalam memberikan suatu tugas tambahan pimpinan disini masih membimbing karyawannya " $\left(\mathrm{MR}, 33^{\mathrm{Th}}\right)$.

Seorang pemimpin dalam organisasi menjadi tonggak keberhasilan dalam pencapaian tujuan organisasi, seperti halnya pada PT. PLN (Persero) Area Situbondo.Kepemimpinan yang dijalankan ini sedikit banyak juga berpengaruh terhadap kinerja karyawan yang bersangkutan yaitu pada PT. PLN (Persero) Area Situbondo. Artinya kepemimpinan ini merupakan faktor dalam mempengaruhi penampilan dan aktivitas bawahan dalam pencapaian tujuan. Jadi, gaya kepemimpinan seorang pemimpin dapat menimbulkan atau menciptakan suasana lingkungan kerja yang nyaman dan juga semangat kerja bagi karyawan pada PT. PLN (Persero) Area Situbondo. Hal ini tentu saja akan berdampak pada kinerja karyawan pada PT. PLN (Persero) Area Situbondo.

Berdasarkan pemaparan di atas dapat disimpulkan bahwa variabel gaya kepemimpinan merupakan salah satu faktor yang mempengaruhi kinerja karyawan pada PT. PLN (Persero) Area Situbondo. Berdasarkan hasil penelitian dan pembahasan dalam penelitian ini membuktikan bahwa hipotesis dalam penelitian ini diterima yaitu diduga ada pengaruh yang signifikan gaya kepemimpinan terhadap kinerja karyawan pada PT. PLN (Persero) Area Situbondo.

\section{PENUTUP}

\section{Kesimpulan}

Berdasarkan analisis data dan hasil pembahasan penelitian yang telah diuraikan pada bab sebelumnya, maka dapat disimpulkan bahwa ada pengaruh yang signifikan gaya kepemimpinan demokratis terhadap kinerja karyawan pada PT. PLN (Persero) area Situbondo. Artinya semakin demokratis kepemimpinan maka akan semakin tinggi kinerja karyawan pada PT. PLN (Persero) area Situbondo, kontribusi pengaruhnya sebesar 80,6\%.

\section{DAFTAR PUSTAKA}

Koesmono, T. 2007. Pengaruh kepemimpinan dan tuntutan tugas terhadap komitmen organisasi dengan variabel moderasi motivasi perawat rumah sakit swasta Surabaya. Jurnal Manajemen dan Kewirausahaan.

Mangkunegara, Prabu Anwar. 2006. Perencanaan dan Pengembangan Manajemen Sumber Daya Manusia. Bandung. PT. Refika Aditama.

Robbins, Stephen P. 2005. Manajement. 8th Edition. Prentice Hall. New Jersey

Robbins, Stephen P., 2006. Perilaku Organisasi: Jakarta. PT. PT Indeks Kelompok Gramedia 
DOI: 10.19184/jpe.v13i1.10415

Robbins, Stephen. 2007. Manajemen. Edisikedelapan / jilid 2. Jakarta, PT. Grafindo

Salusu. J. 2006. Pengambilan Keputusan Strategik Untuk Organisasi Publik dan Organisasi Non Profit. Jakarta Siagian. SP. 2001. Teori Motivasi dan Aplikasinya. Jakarta: Rineka Cipta

Thoha, Miftah. 2010. Kepemimpinan Dalam Manajemen, Devisi Buku Perguruan Tinggi :Jakarta. PT. Raja Grafindo Persada.

Thoha, Miftah. 2013. Kepemimpinan Dalam Manajemen, edisi 1 : Jakarta. PT. Raja Grafindo Persada.

Tjiptono, Fandy. 2006. Manajemen Jasa. Edisi Pertama. Yogyakarta: Andi 